\title{
BADANIA GEOSYNTETYKÓW Z WYKORZYSTANIEM METODY DIGITAL IMAGE CORRELATION
}

\begin{abstract}
Dokładne wyznaczenie odkształceń i naprężeń w poddanych obciążeniom materiałach geosyntetycznych stanowi istotne zagadnienie zarówno z punktu widzenia naukowego jak i praktycznego. Materiały geosyntetyczne są coraz bardziej popularne w budownictwie komunikacyjnym, a ciągły rozwój tych produktów wskazuje na równoczesną potrzebę zastosowania nowych metod badawczych umożliwiających pełną ocenę ich parametrów mechanicznych. W niniejszym artykule przedstawiono wyniki pierwszych prac zrealizowanych z wykorzystaniem nowoczesnej metody Digital Image Correlation (DIC), umożliwiającej bezkontaktowe wyznaczanie przemieszczeń i odkształceń próbek materiałów geosyntetycznych bazując na analizie optycznej. Oprócz standardowego obrazu deformacji dla uśrednionej bazy możliwa jest analiza odkształceń na dowolnym kierunku i dla dowolnej bazy wewnątrz badanego obszaru.
\end{abstract}

Słowa kluczowe: geosyntetyki, cyfrowa korelacja obrazu, badania wytrzymałościowe

\section{Wprowadzenie}

Dokładne określenie odkształceń i naprężeń występujących w poddanych obciążeniom materiałach geosyntetycznych stanowi ważne zagadnienie zarówno z punktu widzenia naukowego jak i praktycznego. Materiały geosyntetyczne są coraz bardziej popularne w budownictwie lądowym, a ciągły rozwój tych produktów wskazuje na równoczesną potrzebę opracowywania i wprowadzania nowych metod badawczych umożliwiających pełną i miarodajną ocenę ich parametrów mechanicznych.

Wg procedury normowej dotyczącej badań geosyntetyków metodą szerokich próbek [9] pomiar deformacji badanego materiału dokonywany jest na jed-

\footnotetext{
1 Autor do korespondencji/corresponding author: Jarosław Górszczyk, Politechnika Krakowska, Wydział Inżynierii Lądowej, 31-155 Kraków; ul. Warszawska 24. Tel: + 4812 628-23-68, jgorszcz@pk.edu.pl

2 Konrad Malicki, Politechnika Krakowska, Wydział Inżynierii Lądowej, 31-155 Kraków; ul. Warszawska 24. Tel: + 4812 628-23-68, kmalicki@pk.edu.pl
} 
nym analizowanym kierunku, tzw. bazy, nie dając informacji o odkształceniach całej powierzchni badanej próbki geosyntetyku.

W niniejszym artykule przedstawiono wyniki pierwszych badań geosyntetyków zrealizowanych z wykorzystaniem nowoczesnej metody Digital Image Correlation (DIC), w literaturze polskojęzycznej określanej jako metoda cyfrowej korelacji obrazu [13] oraz porównano je z wynikami uzyskanymi tradycyjną metodą pomiarową. System opierający się na metodzie DIC umożliwia bezkontaktowe wyznaczenie przemieszczeń i odkształceń próbek materiałów w badaniach statycznych i zmęczeniowych, bazując na optycznej analizie deformacji próbki $[4,5]$. Główną zaletą systemu jest możliwość analizy deformacji wszystkich obserwowanych $w$ trakcie badania punktów znajdujących się na powierzchni próbki. Metoda DIC może zostać z powodzeniem wykorzystana w analizach deformacji różnych materiałów budowlanych, w tym kompozytów takich jak np. mieszanki mineralno-asfaltowe, beton cementowy $[3,10,11]$.

W niniejszym artykule opisano statyczne badania wytrzymałościowe z wykorzystaniem systemu DIC geosiatki Fortrac przeznaczonej do zastosowań geotechnicznych $[1,2]$ oraz geosiatki szklanej S\&P Glasphalt G przeznaczonej do zbrojenia warstw asfaltowych nawierzchni drogowych [8].

\section{Metody badań}

\subsection{Metoda Digital Image Correlation (DIC)}

System DIC może zostać zaimplementowany na odpowiednio przygotowanym stanowisku laboratoryjnym realizującym badania mechaniczne i termomechaniczne próbek różnych materiałów i o różnej geometrii $[3,5,11,13]$. Głównymi elementami wyposażenia systemu są kamery, kontroler oraz komputer z odpowiednim oprogramowaniem. Schemat stanowiska laboratoryjnego bazującego na metodzie DIC pokazano na rysunku 1, a schemat działania systemu pokazano na rysunku 2.

System DIC umożliwia wyznaczanie odkształceń badanego geosyntetyku na dowolnym kierunku i $\mathrm{w}$ dowolnym punkcie bez konieczności stosowania tensometrów, pozwala również na rozwiązanie zagadnienia wartości i wektorów własnych dla analizowanej powierzchni. System ten można z sukcesem stosować do wyznaczania modułów Younga i współczynników Poissona, rozpoznania zjawiska osłabienia bądź umocnienia materiału w szerokim zakresie odkształcenia plastycznego. 


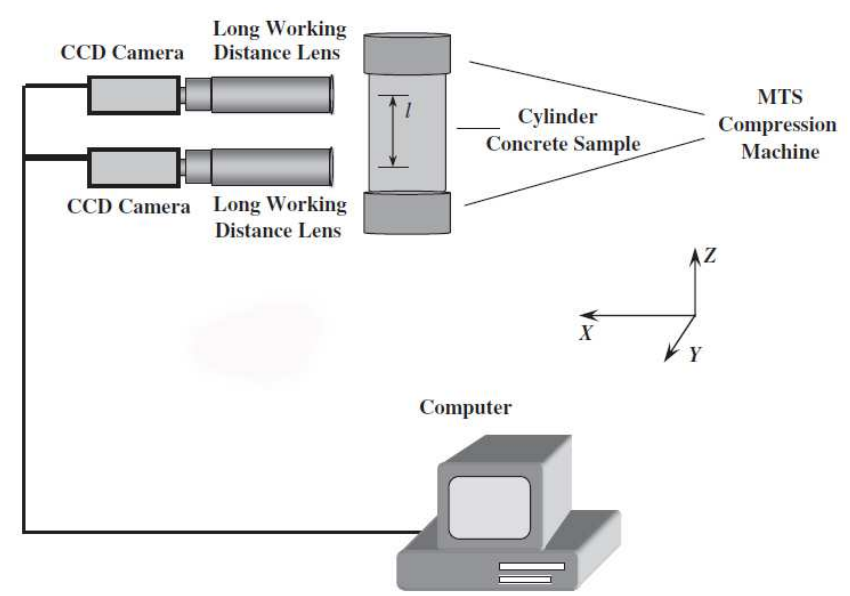

Rys. 1. Schemat stanowiska laboratoryjnego wyposażonego w system DIC- na podstawie [7]

Fig. 1. The laboratory testing stand with the DIC system - based on [7]

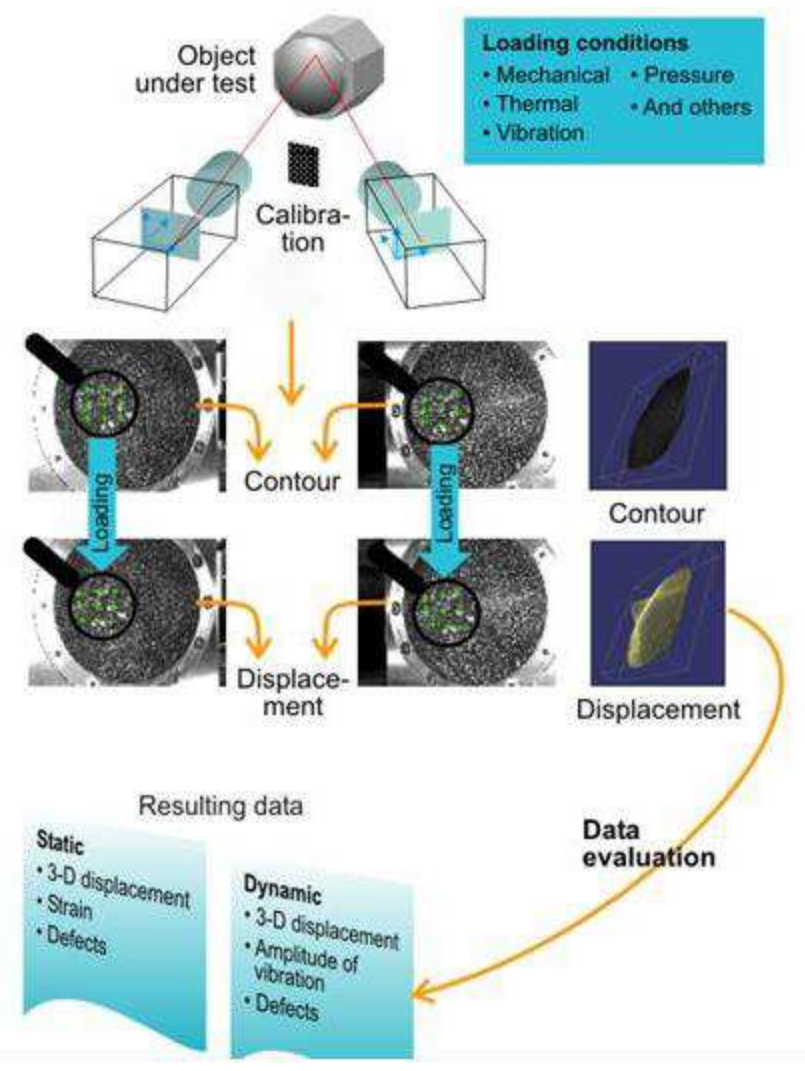

Rys. 2. Schemat działania systemu DIC - na podstawie [4]

Fig. 2. Functional diagram of the DIC system - based on [4] 
Kamera cyfrowa systemu analizująca obszar wyszukuje na powierzchni badanego geosyntetyku punkty charakterystyczne, które stają się punktami odniesienia dla wirtualnej siatki/dyskretyzacji analizowanej powierzchni. Na podstawie rejestrowanych zmian odległości między punktami oraz ewaluacji numerycznej tworzona jest mapa przemieszczeń i odkształceń dla całej widzianej przez kamerę powierzchni badanego materiału. Wyniki pomiarów mogą być przedstawiane graficznie w postaci wyskalowanych kolorowych map.

$\mathrm{W}$ analizach zmian położenia punków na powierzchni badanej próbki wykorzystywane są dwa modele, pierwszy bazujący na przekrojowym współczynniku korelacji (NCC) i drugi bazujący na doborze najmniejszych kwadratów (LSM) [11, 12]. W metodzie NCC dla każdej pozycji obliczany jest współczynnik korelacji $\rho$ pomiędzy początkowym (stanem niezdeformowanym) i bieżącym położeniem punktów (stanem zdeformowanym). Wybierana jest najbliższa lokalizacja na poziomie piksela poprzez wybór minimalnej wartości wspólnego przekrojowego współczynnika korelacji. Funkcja korelacji przekrojowej estymowana jest po poszukiwanym obszarze, jej maksimum wskazuje najlepsze dopasowanie. Współczynnik $\rho$ obliczany jest z dyskretnej funkcji przemieszczeń $(\Delta x, \Delta y)$ i wartości średnich $\overline{\mathrm{f}}$ i $\overline{\mathrm{g}}$ funkcji poziomu szarości $f(x, y)$ i $g(x, y)$ porównywanych obszarów wg równania (1) [12]:

$$
\rho=\frac{\sum_{x} \sum_{y}(f(x, y)-\bar{f}) \times(g(x+\Delta x, y+\Delta y)-\bar{g})}{\left(\sum_{x} \sum_{y}(f(x, y)-\bar{f})^{2} \times \sum_{x} \sum_{y}(g(x+\Delta x, y+\Delta y)-\bar{g})^{2}\right)^{1 / 2}}
$$

Algorytm metody NCC jest szybszy, jednak rozpatrywane są jedynie przesunięcia zbiorów punktów na osi pionowej i poziomej, nie uwzględniając ich obrotów. W metodzie LSM wykorzystywane są bardziej skomplikowane modele i równania funkcji, umożliwiające rozpatrywanie zarówno translacji jak i rotacji zbioru punktów. Najlepsze dopasowanie definiowane jest poprzez minimalizację różnicy poziomów szarości obszarów pomiędzy dwoma kolejnymi krokami (obrazami) analizy przy użyciu metody najmniejszych kwadratów. Korekta parametrów uwzględniająca przesunięcia i obroty wyznaczana jest wg równania (2), w którym $(a 1, a 2, b 1, b 2)$ są zmiennymi parametrami kształtu, parametry $(a 3, b 3)$ to parametry przesunięcia, $e\left(x_{1}, y_{1}\right)$ jest funkcją residualną dla punktu $\left(x_{1}, y_{1}\right)$ w obrazie referencyjnym obszaru (niezdeformowanym), $r_{0}, r_{1}$ to odpowiednio parametry zmiany jasności i kontrastu obrazu w trakcie badania [11, 12]:

$$
\begin{aligned}
f\left(x_{1}, y_{1}\right)+e\left(x_{1}, y_{1}\right)= & r_{0}+r_{1} \cdot g\left(x_{2}(u, v), y_{2}(u, v)\right)= \\
& =\bar{g}\left(r_{o}, r_{1}, a_{1}, a_{2}, a_{3}, b_{1}, b_{2}, b_{3},\right)
\end{aligned}
$$

Funkcja $\bar{g}\left(r_{o}, r_{1}, a_{1}, a_{2}, a_{3}, b_{1}, b_{2}, b_{3},\right)$ jest linearyzowana i rozwiązywana wg metody estymacji najmniejszych kwadratów Gaussa - Markova. 


\subsection{Badanie wytrzymałości geosyntetyków na rozciąganie metodą sze- rokich próbek}

Badania wytrzymałościowe przeprowadzono bazując na normie PN-EN ISO 10319:2015 [9]. Wg procedury normowej określenie odkształcenia próbki dokonywane jest na podstawie rejestracji zmiany długości bazy pomiarowej o długości $60 \mathrm{~mm}$ usytuowanej w środkowej części próbki na kierunku równoległym do kierunku zadawanej siły rozciągającej. Norma dopuszcza pomiar deformacji przy użyciu urządzeń mechanicznych, optycznych, podczerwieni lub innych z wyjściem elektrycznym. Próbki do badań powinny mieć $200 \mathrm{~mm}$ szerokości i być takiej długości, aby po zamocowaniu ich w szczękach, pomiędzy szczękami znajdowało się minimum $100 \mathrm{~mm}$ długości próbki. Minimalna liczba próbek to 5 dla każdego badanego kierunku. Wynikiem badania jest wytrzymałość średnia próbki na rozciąganie.

\section{Stanowisko badawcze i przygotowanie próbek}

\subsection{Materiały geosyntetyczne wykorzystane w badaniach}

W badaniach wykorzystano próbki przygotowane $\mathrm{z}$ geosiatki Fortrac 40/40-35T [1,2] oraz siatki szklanej S\&P Glasphalt G [8].

Geosiatki Fortrac przeznaczone są do wykorzystania w budownictwie komunikacyjnym między innymi do wzmacniania słabego podłoża gruntowego, zbrojenia nasypów i stabilizacji osuwisk [6].

Geosiatka S\&P Glasphalt G przeznaczona do zbrojenia warstw asfaltowych wykonana jest $\mathrm{z}$ włókien szklanych oraz powlekana jest warstwą bitumiczną z jednostronną posypką z piasku i ochronną folią poliestrową, zabezpieczającą przed sklejeniem się materiału podczas składowania [8].

\subsection{Przygotowanie próbek}

Do badań przygotowano 20 próbek materiałów geosyntetycznych o wymiarach 20x30 cm każda. Powierzchnia próbek do pomiarów z wykorzystaniem systemu DIC wymagała specjalnego przygotowania. W pierwszej kolejności próbki zostały pokryte warstwą białej farby. Następnie na tak przygotowanej powierzchnię rozpylono czarną farbę, tworząc wzór drobnych, czarnych punków na białym tle. Próbki przygotowane do badań pokazano na rysunku nr 3 . 

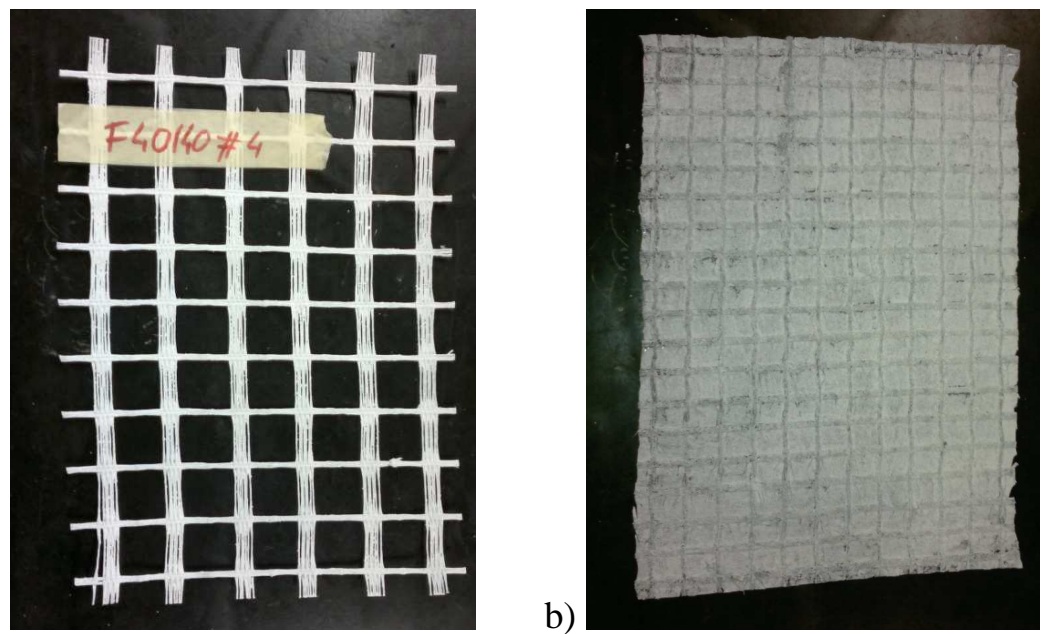

Rys. 3. Próbki geosyntetyków przygotowane do badań: a) Fortrac, b) Glasphalt G

Fig. 3. Geosynthetic samples prepared for testing: a) Fortrac, b) Glasphalt G

\subsection{Stanowisko badawcze i parametry badań}

Badania geosyntetyków przeprowadzono na laboratoryjnym stanowisku badawczym, którego najważniejszymi elementami są [3]: stanowisko serwohydraulicznej maszyny wytrzymałościowej, kontroler i komputer sterujące systemem DIC, kamery cyfrowe systemu DIC, odpowiednie oświetlenie liniowe.

Badania przeprowadzono $\mathrm{w}$ temperaturze $+20^{\circ} \mathrm{C}$, prędkość odkształceń przyjęto wg [9]. Widok stanowiska pokazano na rysunku $\mathrm{nr} 4$.

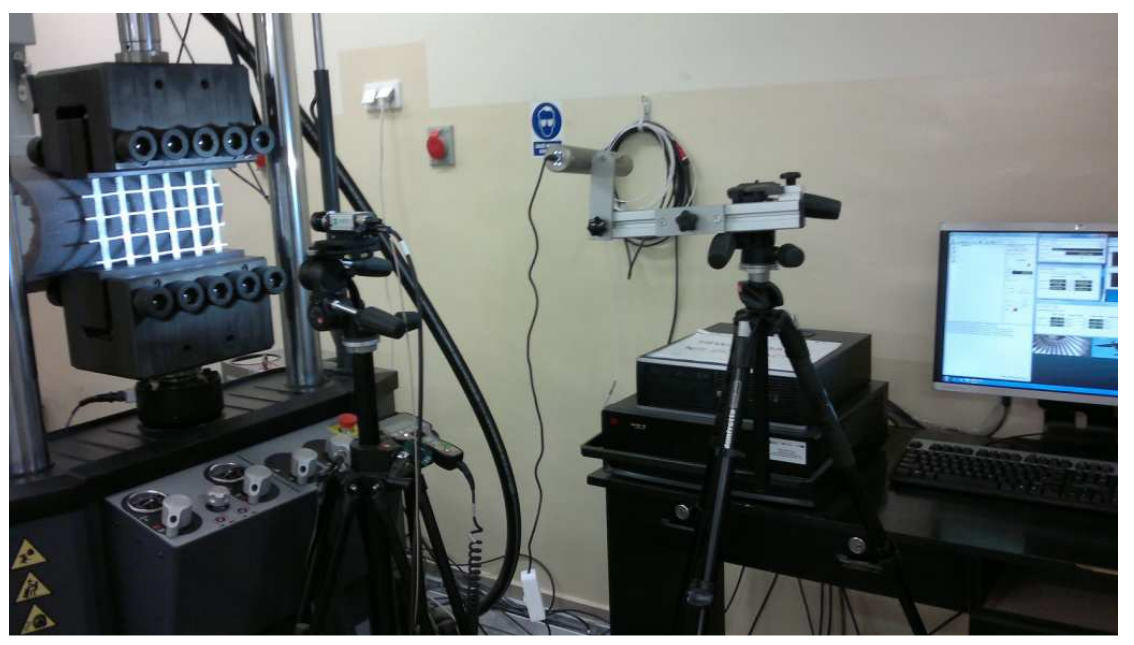

Rys. 4. Stanowisko laboratoryjne do badań geosyntetyków z wykorzystaniem metody DIC

Fig. 4. The laboratory stand for geosynthetic testing using the DIC method 


\section{Wyniki badań}

W tabelach 1 i 2 zamieszczono porównanie wartości odkształcenia liniowego wertykalnego wg normy [9] wyznaczonego przy użyciu dwóch technik pomiarowych dla różnych poziomów obciążenia. Uzyskane w tym zakresie wyniki nie wykazały istotnych różnic, wskazując jednocześnie na poprawność działania systemu DIC i jego dodatkowe możliwości. Na rysunku 5 przedstawiono wykres zmiany odkształcenia liniowego wertykalnego próbki materiału geosyntetycznego wyznaczony z wykorzystaniem systemu DIC w obszarze tradycyjnej bazy pomiarowej ekstensometru.

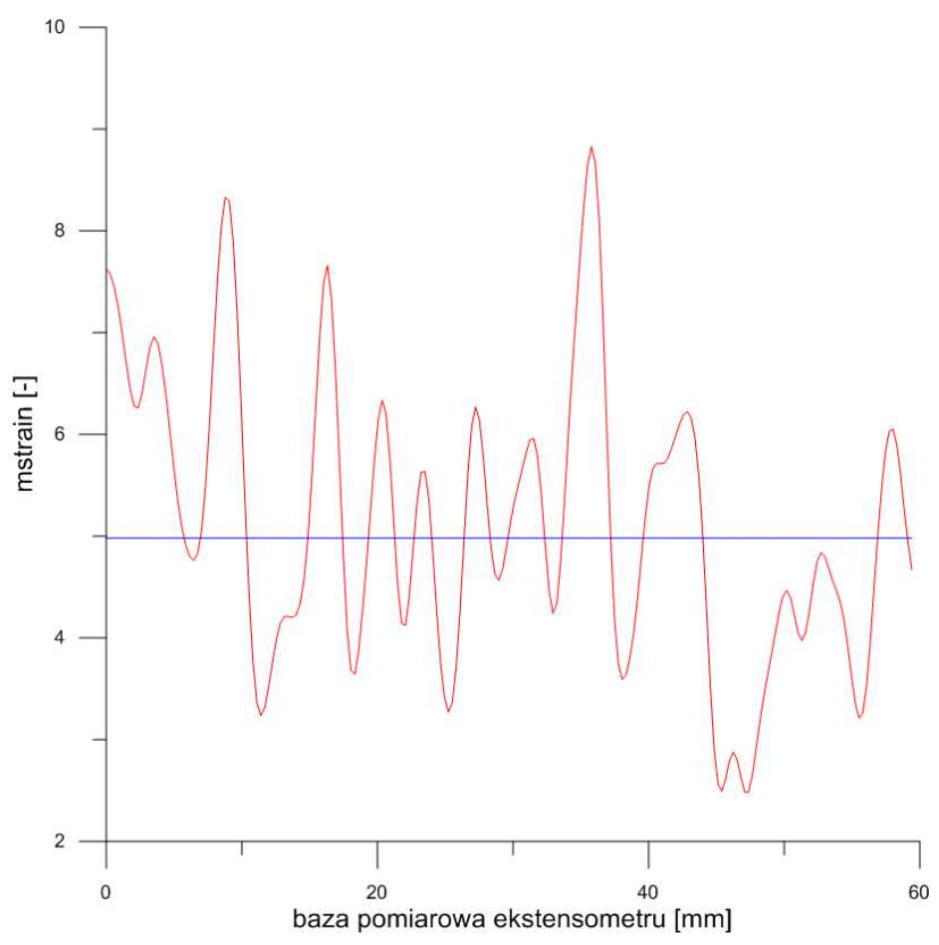

Rys. 5. Zmienność odkształcenia liniowego wertykalnego w bazie ekstensometru (kolor czerwony), odkształcenie wyznaczone techniką tensometryczną (kolor niebieski), próbka geosyntetyku szklanego, obciążenie $4,5 \mathrm{kN}$

Fig. 5. Distribution of tensile strain at tested distance (red color), tensile strain measured with using of the extensometer (blue color), the glass geosynthetic sample, load $4.5 \mathrm{kN}$ 
Tabela 1. Wartości średnie odkształceń z 5 próbek, geosyntetyk poliestrowy (kierunek osnowa)

Table 1 . The tensile strain average values of 5 samples, polyester geosynthetics

\begin{tabular}{|c|c|c|c|}
\hline \multirow{2}{*}{ Obciążenie } & \multicolumn{2}{|c|}{ Odkształcenie liniowe wertykalne } & \multirow{2}{*}{ Stosunek wyników } \\
\cline { 2 - 3 } & $\begin{array}{c}\text { Technika } \\
\text { tensometryczna }\end{array}$ & $\begin{array}{c}\text { DIC (uśrednienie } \\
\text { dla bazy } 60 \mathrm{~mm} \text { ) }\end{array}$ & \\
\hline 1 & 2 & 3 & $3 / 2$ \\
\hline $2,64 \mathrm{kN}$ & $30010^{-4}$ & $336 \cdot 10^{-4}$ & 1,12 \\
\hline $6,27 \mathrm{kN}$ & $60010^{-4}$ & $654 \cdot 10^{-4}$ & 1,09 \\
\hline $10,83 \mathrm{kN}$ & $90010^{-4}$ & $965 \cdot 10^{-4}$ & 1,07 \\
\hline
\end{tabular}

Tabela 2. Wartości średnie odkształceń z 5 próbek, geosyntetyk szklany (kierunek osnowa)

Table 2. The tensile strain average values of 5 samples, glass geosynthetics

\begin{tabular}{|c|c|c|c|}
\hline \multirow{2}{*}{ Obciążenie } & \multicolumn{2}{|c|}{ Odkształcenie liniowe wertykalne } & \multirow{2}{*}{ Stosunek wyników } \\
\cline { 2 - 3 } & $\begin{array}{c}\text { Technika } \\
\text { tensometryczna }\end{array}$ & $\begin{array}{c}\text { DIC (uśrednienie } \\
\text { dla bazy } 60 \mathrm{~mm} \text { ) }\end{array}$ & \\
\hline 1 & 2 & 3 & $3 / 2$ \\
\hline $18,49 \mathrm{kN}$ & $20010^{-4}$ & $209 \cdot 10^{-4}$ & 1,05 \\
\hline $22,10 \mathrm{kN}$ & $25010^{-4}$ & $273 \cdot 10^{-4}$ & 1,09 \\
\hline $16,89 \mathrm{kN}$ & $30010^{-4}$ & $324 \cdot 10^{-4}$ & 1,08 \\
\hline
\end{tabular}

Wirtualną siatkę/dyskretyzację analizowanego obszaru geosyntetyku poliestrowego oraz wybrane wyniki badań laboratoryjnych $\mathrm{w}$ postaci kolorowych map przedstawiono na rysunkach $\mathrm{nr}$ 6-10.

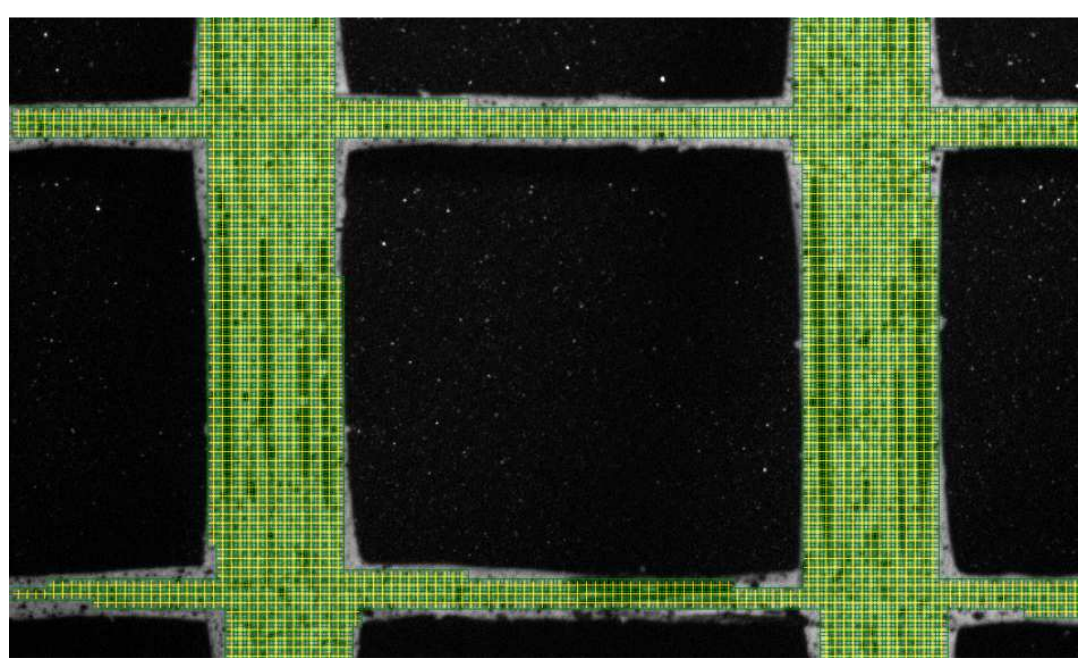

Rys. 6. Siatka metody DIC - próbka geosyntetyku Fortrac

Fig. 6. Grid of the DIC method - Fortrac geosynthetic sample 


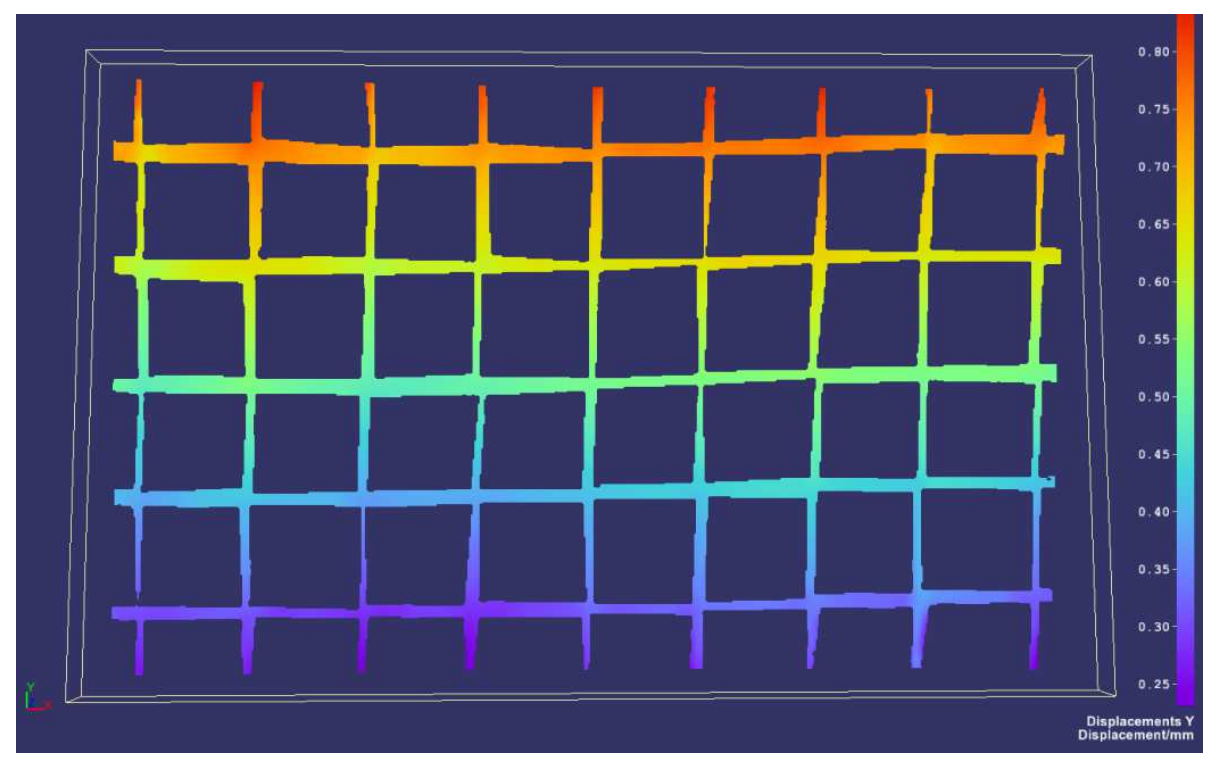

Rys. 7. Rozkład przemieszczeń wertykalnych na powierzchni próbki geosyntetyku Glasphalt G Fig. 7. Distribution of vertical displacements of Glasphalt G geosynthetic sample

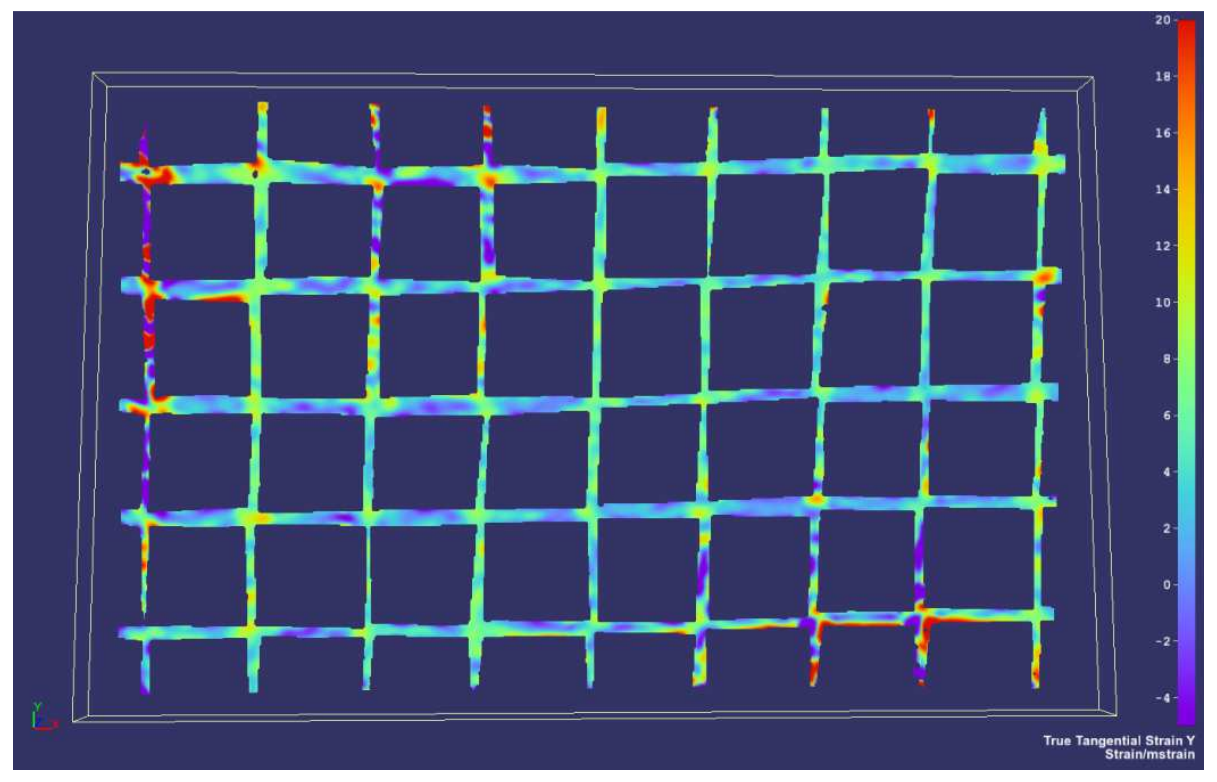

Rys. 8. Rozkład odkształceń liniowych pionowych na powierzchni geosyntetyku Glasphalt G, obciążenie $14,5 \mathrm{kN}$

Fig. 8. Distribution of vertical tangential strain of Glasphalt G geosynthetic sample, load 14,5 KN 


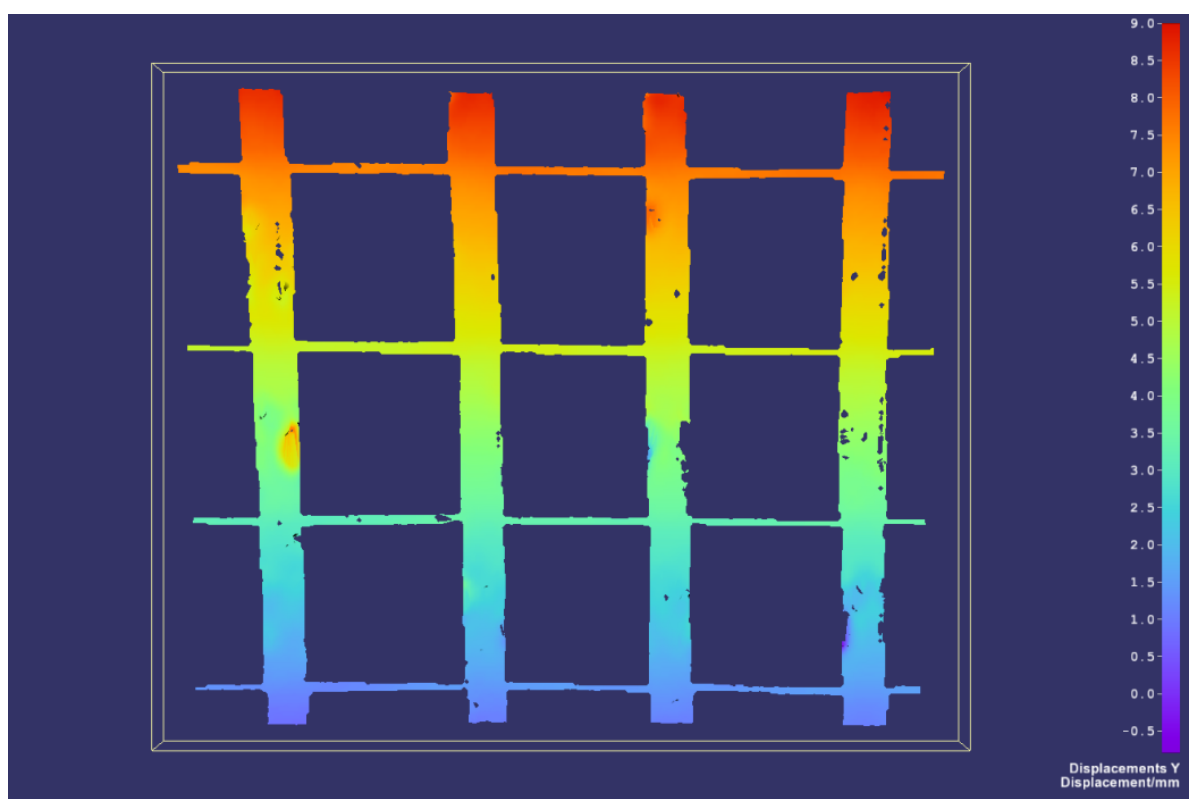

Rys. 9. Rozkład przemieszczeń wertykalnych na powierzchni próbki geosyntetyku Fortrac Fig. 9. Distribution of vertical displacements of Fortrac geosynthetic sample

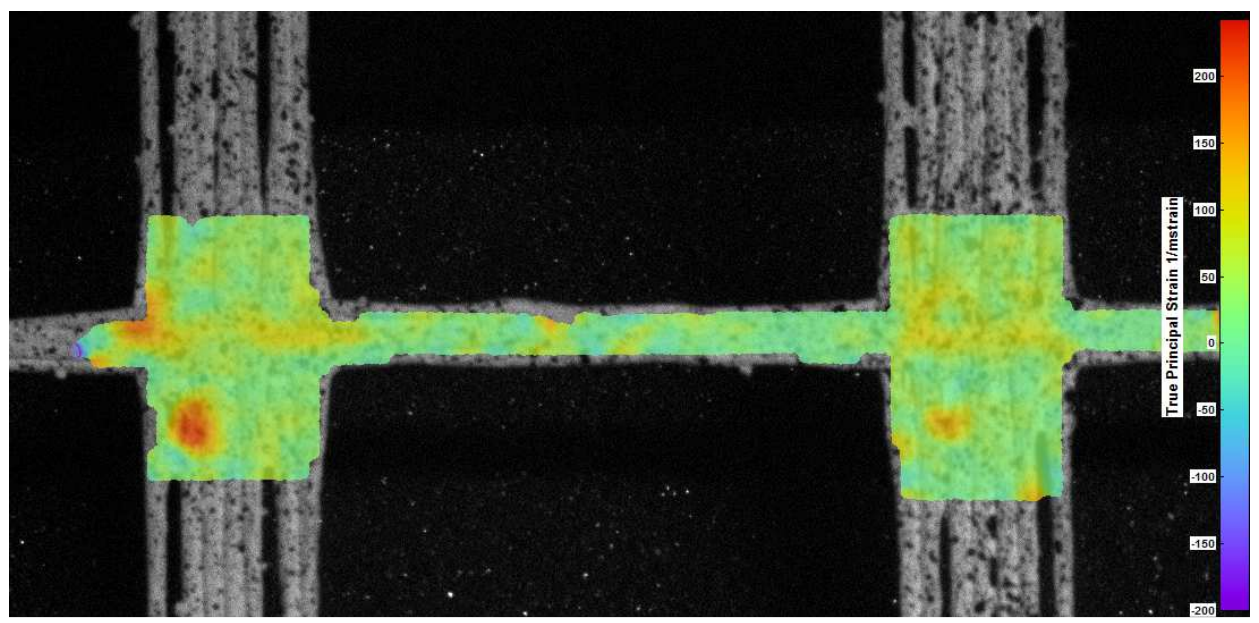

Rys. 10. Rozkład odkształceń głównych na powierzchni węzłów próbki geosyntetyku Fortrac, obciążenie 2,3 kN

Fig. 10. Distribution of principal strain of Fortrac geosynthetic sample node, load 2,3 kN 


\section{Wnioski}

Wyniki przeprowadzonych badań i analiz materiałów geosynetycznych umożliwiły sformułowanie następujących wniosków:

- Metoda Digital Image Correlation (DIC) zaimplementowana na odpowiednio przygotowanym stanowisku laboratoryjnym umożliwia skuteczne pomiary deformacji geosyntetyków w badaniu rozciągania metodą szerokich próbek.

- Zastosowana metoda umożliwia określenie całościowego, powierzchniowego charakteru pracy geosyntetyku, dając możliwość wyznaczenia miejsc najbardziej wytężonych, również poza bazą - wykrywanie pęknięć (rysunki 8 i 10).

- Możliwość wyznaczenia pola przemieszczeń i odkształceń dla całej powierzchni próbki geosyntetyku wraz z rozwiązaniem zagadnienia wartości i wektorów własnych stanowi dużą zaletę metody, gdyż jest nieosiągalne z użyciem tradycyjnych metod pomiarowych - tensometrów (rysunki 7 i 9).

- Zastosowana metoda pomiarowa otwiera również możliwości dla walidacji modeli geosyntetyków wykonanych z wykorzystaniem metody elementów skończonych (MES).

- Metoda DIC pozwala w badaniach wytrzymałościowych geosyntetyków w pełni uwzględnić i zobrazować specyficzną deformację siatek jako struktur niejednorodnych i anizotropwych (rysunek 10).

- Zastosowany algorytm numeryczny umożliwia wyeliminowanie ruchu próbki jako bryły sztywnej w trakcie badania. Pozwala to np. na ograniczenie wpływu problemu związanego z możliwością wysuwania się próbek badanego geosyntetyku z zacisków szczęk aparatury badawczej.

- W niniejszym artykule zaprezentowano wyniki pierwszych badań, a pełne, optymalne wykorzystanie metody DIC w badaniach wytrzymałościowych geosyntetyków wymaga dalszych prac implementacyjnych.

- W kolejnych pracach badaniom poddane zostaną geosyntetyki trzy i czteroosiowe oraz geokompozyty. Przypuszcza się, iż metoda DIC umożliwi analizę wpływu węzłów na pracę całego geosyntetyku oraz stworzy możliwość do analizy pól odkształceń poszczególnych komponentów w układach kompozytowych.

\section{Literatura}

[1] Fortrac - Immensely Versatile Solutions for Reinforced Soil. 11/15 B HUESKER Synthetic GmbH, Gescher 2015.

[2] Geosiatki Fortrac w konstrukcjach z gruntów zbrojonych. Przedsiębiorstwo realizacyjne Inora Sp. z o. o. Wydanie II.

[3] Górszczyk J., Malicki K.: Przenośny system cyfrowej korelacji obrazu 2D do wyznaczania przemieszczeń i odkształceń próbek materiałów drogowych. Logistyka 6 , 2014.

[4] http://www.dantecdynamics.com $\{18.11 .2015 \mathrm{r}\}$. 
[5] http://www.elhys.com $\{21.05 .2016 \mathrm{r}\}$.

[6] http://www.huesker.pl/geos.html\{14.05.2016 r\}.

[7] Huang Y.H., Liu L., Sham F.C., Chan Y.S., Ng S.P., Optical strain gauge vs. traditional strain gauges for concrete elasticity modulus determination. Optik - International Journal for Light and Electron Optics, Volume 121, Issue 18, 2010.

[8] Karta techniczna siatki S\&P Glasphalt G, 2013, http://www.sp-reinforcement.eu

[9] PN-EN ISO 10319:2015 Geosyntetyki, Badanie wytrzymałości na rozciąganie metodą szerokich próbek.

[10] Romeo E., Montepara A.: Characterization of reinforced asphalt pavement cracking behavior using flexural analysis, SIIV - 5th International Congress - Sustainability of Road Infrastructures, Procedia - Social and Behavioral Sciences, vol. 53, 2012, pp. $356-365$.

[11] Romeo E.: Two-dimensional digital image correlation for asphalt mixture characterisation: interest and limitations, Road Materials and Pavement Design, vol. 14, no. 4, 2013, pp. $747-763$.

[12] Sutton M. A., Orteu J., Schreier H. W.: Image Correlation for Shape, Motion and Deformation Measurements, Springer Science+Business Media, LLC 2009, New York.

[13] Szymczak T., Grzywna P., Kowalewski Z.: Nowoczesne metody określania wytrzymałościowych właściwości materiałów konstrukcyjnych, Transport samochodowy $\mathrm{nr}$ 1, 2013.

\section{RESEARCH ON GEOSYNTHETICS USING DIGITAL IMAGE CORRELATION METHOD}

\section{S u m m a r y}

The exact determination of stresses and strains occurring in loaded geosynthetic materials is an important issue both from the scientific point of view as well as practical one. Geosynthetic materials are becoming more and more popular in civil engineering and the continuous development of these products indicates the need for simultaneous application of new research methods to enable a full assessment of their mechanical parameters. This article presents the first results of the work carried out using an innovative method of Digital Image Correlation (DIC), enabling contactless determination of deformations of geosynthetic samples based on optical analysis. With using of this method it is possible to analyze deformation in any direction within the study area.

Keywords: geosynthetic, Digital Image Correlation, strength tests

Przestano do redakcji: 07.06.2016 $r$.

Przyjęto do druku: 30.06 .2016 r.

DOI: $10.7862 / \mathrm{rb} .2016 .61$ 